\title{
Dynasty Politics in Succession of Village Leadership: A Case Study in the Village of Cileunyi Wetan, Indonesia
}

\author{
Hadi Prabowo', Sri Hartati ${ }^{2}$ \\ 1,2 Institut Pemerintahan Dalam Negeri (IPDN), Indonesia \\ Email: hadi.prabowo@gmail.com,srihartatiipdn@gmail.com
}

\begin{abstract}
The purpose of this research is to find out the factors causing dynastic politics and the impact of dynastic politics on village leadership for community development in Cileunyi Wetan Village, Cileunyi District, Bandung Regency. This study uses qualitative methods with data collection techniques such as interviews, observation, and study documentation. Dynasty politics is a process of regenerating power for the interests of the political elite that aims to maintain power by placing their families or relatives in certain positions in the field of government. The practice of dynastic politics in the village of Cileunyi Wetan was an attempt to maintain power by the village head's family for several periods. The relationship between the village head and the former village head was uncle and father, who still had influence in the community. The dynasty in the village leadership in the village of Cileunyi Wetan was caused by the strength of capital (economy), the strength of family networks, and the existence of unhealthy democratic practices. The dynastic political impact of village leadership on community development in the village of Cileunyi Wetan is the control of economic resources in the village by a group of people, and the existence of nepotism in the recruitment of village government officials.
\end{abstract}

Keywords: Dynasty Politics, Local Politics, Village Government.

\section{A. INTRODUCTION}

The New Order had a very significant impact on changes in the political system and governance in Indonesia, one of which was marked by political liberalization at the national and local levels, meaning that the Indonesian political system underwent a change from a non-democratic political system to a democratic one. But this change does not necessarily end the old political system (dynastic politics) which was born and developed during the new order.

Dynasty politics is a political power that is exercised by a group of people who are still involved in family relations or close relatives. Basically dynastic politics gave rise to many pros and cons. Some consider it good because political stability is maintained and some others think that dynastic politics is only a tool used by officials to perpetuate their power, besides dynastic politics can narrow the opportunity for others to participate in political institutions because usually, the prospective leader results from dynastic politics more support (Cipto, 1999).

Dynasty politics is a group of people or the ruling elite who still have close family relationships that support each other and alternately occupy power through elections 
in their respective periods (Rozali, 2015). According to Agustino (2011), dynastic politics is a "political empire" where political elites place their family, relatives, and relatives in several important government positions both local and national, or can be said to form strategies such as a structured and systematic royal network. Dynasty politics or family politics have a special characteristic, which plays a major role in top-level government while the people only choose to play behind. In this politics, there is almost no place for politicians who do not have kinship or kinship.

With the development of dynastic politics, it is very likely that the people will only be presented with the same political actors from one family. Dynasty politics emerged in various forms, such as by encouraging relatives to continue to hold power in a democratic manner. According to Hidayati (2014), the factors that led to the emergence of dynastic politics were: position in the party, network strength, capital strength, and unhealthy democracy.

Village leadership is the leadership of the village administration based on policies set together with the Village Consultative Body (BPD) or the Pemekonan (BHP), in other words that the Village Head is the leader of the village executive body assisted by village officials who have been formed by the Village Head to help carry out his duties (Nurcholis, 2011). Village Head is a person chosen to lead in a community unit that has territorial boundaries that are authorized to regulate and manage the interests of the local community. The village head is also a village government apparatus who is also directly elected by the community to serve as the leader of a village.

A village head has the duty and responsibility for the progress of the village. The village government is the leader of a legal community unit that has the authority to regulate and manage the interests of the local community based on local origins and customs (Widjaja, 2001).

Dynasty politics eliminate equality which is one of the important values in a democracy. The democratic political system that was presented by the New Order actually gave room for the growth and development of dynastic politics, as found in the village of Cileunyi Wetan. The village of Cileunyi Wetan is one of the villages in the area of Kacamatan Cileunyi, Bandung Regency. The village of Cileunyi Wetan, Kacamatan Cileunyi, Bandung Regency is famous for its high sense of kinship. It is possible to make a leader of a family that has the influence of a strong family, the political system in the village of Cileunyi Wetan shows the existence of a family.

The phenomenon of village leadership having family relations with previous officials has been thoroughly examined, including Tristana \& Priyatno (2017); Komar (2013); Sri (2018); Pahruddin (2017); and Hafiz (2018). But this research has a focus which is based on previous research. Based on the description above, the purpose of this study is to determine the factors that cause dynastic politics and dynastic political impact in village leadership for community development in the village of Cileunyi Wetan, Kacamatan Cileunyi, Bandung Regency. 


\section{B. METHOD}

This research was conducted in the village of Cileunyi Wetan, Cileunyi District, Bandung Regency using qualitative methods (Moleong, 2014; Craswell, 2014). Data collection techniques through in-depth interviews, observation, and study of documentation. There were 8 informants in this study consisting of village officials, religious leaders, and local community members. Data analysis was performed interactively using the Miles \& Huberman (1994) model.

\section{Result AND Discussion}

\section{Factors That Cause Dynastic Politics}

In the government system in Indonesia, the village government is the lowest government unit that is directly related to people's lives. The village head is a person who has been democratically elected through direct election by the local community who have voting rights based on existing regulations. The village head has great authority in organizing the village government. In its implementation, a village head is assisted by several village officials such as the head of affairs, the village head, as well as the BPD. They have relations with one another. The relationship is a relationship that is established by someone with someone else or someone with an institution (Kartono, 2010). Every relationship has a relationship that is well established. For example, in a village administration, a Village Head also has a certain term of office and will cease to occupy that position. The village head who has finished his term of office is usually called the former village head. Throughout the village administration in the village of Cileunyi Wetan, there has been a change of village heads several times.

Kinship politics or dynastic politics is a regeneration of power for the interests of certain political elite groups that aim to obtain or maintain power based on kinship. One of the political practices of kinship that is currently underway is found in the village of Cileunyi Wetan, where there has been an effort to maintain power by the village head's family, while the factors that led to dynastic politics are as follows:

a. Capital Strength (Economy)

Economic capital can be said as a consideration in the nomination to become a leader. Wealth owned by a person is very influential in society as a basic capital to achieve a goal or victory. The author found based on the results of research that the economic ability of a village head is also a consideration in the nomination, being a village head is not drowned with capital abilities in politics alone but also has the ability economically. With the mastery of economic resources or wealth owned by the village head showing their class greatly influences the community, it is easy for them to gain sympathy or support from the community as far as possible to achieve a goal or victory.

b. Network Strength (Family)

Kinship is social units consisting of several families that have blood relations or marital relations, the family is a core social institution. The family is divided into two, 
namely the nuclear family consisting of father, mother, and child and the extended family which is a collection of nuclear families that are interconnected because of blood and living together. The family political network is caused by an element of the relationship between the authorities and one network that looks at the perspective of interests. Interest is one of the keys to forming a relationship towards a social exchange in a network of power.

The highest positions of government both at the central and village levels are an attempt to gain power. the strategy is a way that is done to maintain what he already has or wants. Various methods are used when we want what we want, the way taken is various. For example, in village governance, various strategies are carried out to maintain power. In the village administration in Cileunyi Wetan Village, the Village Head has a certain strategy in perpetuating his authority. The influence of the former village head was very large in the implementation of the next village head election. The village head's success came from family support in village leadership. Maurer mentioned about the village bureaucracy, that the position of Village Head in rural Java was monopolized by the family of the former Village Head. He also mentioned that nepotism was widespread in rural Java. The practice of inheritance and also the emergence of "local dynasties" in village bureaucrats who monopolize various positions in matters of community management. important positions in the village are usually held by people who have a close relationship with the Village Head. Evidenced by the existence of the position of Village Head starting from the Government, Head of People's Welfare, RT, Head of RW, and General Board who still have kinship ties.

c. Democracy is not healthy

In the regional head election and general election, there is a lot of fraud, one of them in the form of money politics or other goods. Money politics is a form of giving or promising to bribe someone to exercise their rights in a certain way during general elections. Money politics is carried out in more structured ways by involving certain parties, money is the basic capital to achieve victory. Here the village head candidate plays his source of power to get as much support. The author found based on the results of research that during the campaign period is very utilized by each candidate who aims to get support. Not infrequently many cheats that occur during the campaign period. Power becomes very important in leadership, the power possessed by a person can maintain his position where he exercises his power, various ways are taken by the Village Head in maintaining power. Actually money politics is a deviant behavior carried out by prospective leaders by giving bribes that have occurred since the candidate registered as a political party so that the mass of the campaign gives promises or other material to influence voters. Because they were born into established families, most family politics (dynastic politics) only wanted to preserve their power. 


\section{The Impact of Dynasty Politics for Community Development}

In dynastic politics, a family or close relative is the right tool to form a powerful power. Power is an ability to influence others to act in accordance with what is given by the giver of the command. In village governance, it also has a power exercised by the Village Head as the holder of the highest position in the village. To keep that power on their side, they maintain power by nominating their wives, children and other relatives to be involved in a government. If power continues to be in the realm of the family, it is feared that such power will not be able to bring social or economic change. The negative impacts of dynastic politics or family politics such as corruption, collusion, nepotism (KKN) and bad development planning.

Along with the times, some people are aware of the importance of education levels. However, community awareness of the level of education is not in line with their crisis in dealing with such a situation of village leadership. The dominance of village leadership by the village head's family does not make the community aware and then make changes. When the level of education gets higher the community should also be increasingly critical of it.

The low education of village government officials is also a determining factor in the quality of public services provided. Public services are the provision of services (serving) and for the welfare of the community. The services provided can be in the form of goods or services that are the responsibility and run by the village government apparatus that aims to prosper the local community. In dynastic politics, dynastic politics are more inclined to think of power than to serve society. In implementing village governance, the Village Head is assisted by several village officials in serving the community well. However, the low level of education and experience becomes a determining factor in the quality of services provided. Unlike the services provided by the former village head before.

Dynasty politics will damage the democratic order because the government comes from family or relatives in part only to seek benefits for their families not for the welfare of society. Dynasty politics will also reduce the opportunity for others to occupy positions. They will place their family or relatives in strategic positions, even if they do not have the integrity or ability in the field of government. Most likely the people will only be presented with the same political actors who come from one family so that many people lose the opportunity to show their ability in the field of government.

The control of economic resources in a family which results in increasingly showing their class greatly influences society. The village head also has a job that does have a reasonable amount of income. Some people said that they were competing with the Village Head because they were unable to compete in terms of the economy they owned. Seola people are accustomed to this condition and regard it as an ordinary thing.

Gramsci argues that the supremacy of a group manifests itself in two ways, as "omission" and as "intellectual and moral leadership". On the one hand, a social group 
dominates opposition groups to subdue them, on the other hand, social groups lead groups of their relatives and allies. A social group must even implement "leadership" before winning government power (leadership is the main ladder to win power). the group then becomes dominant when it can exercise power, but even if he holds full power in his hands he still has to "lead" as well.

\section{CONCLUSION}

Factors causing dynastic politics in the village of Cileunyi Wetan, District of Cileunyi, Bandung Regency are the capital strength (economy) of the village head candidate, the strength of the network (family) of the village head candidate, and the unhealthy democracy in the form of money politics. The impact of dynastic politics in the village of Cileunyi Wetan, Cileunyi Subdistrict, Bandung Regency is the control of economic resources in the village by the village head's family and the low level of education of the village government apparatus due to nepotism at the time of appointing village officials.

\section{REFERENCES}

1. Agustino, L. (2011). Sisi Gelap Otonomi Daerah: Sisi Gelap Desentralisasi di Indonesia Berbanding Era Sentralisasi. Bandung: Widya Padjadjaran.

2. Cipto, B. (1999). Indonesia Memasuki Era Politik Dinasti: Dari Bilik Suara Kemasa Depan Indonesia Potret Konflik Pasca Pemilu dan Nasib Reformasi. Jakarta: Raja Grafindo Persada.

3. Creswell, J. W. (2014). Research Design: Qualitative, Quantitative and Mixed. Methods Approaches. Sage publications, Inc.

4. Hafiz, M. (2018). Dinasti Politik (Reproduksi Kekuasaan dalam Dinasti Bani Husain di Desa Sera Tengah). Komunitas, 7(3), 384-402.

5. Hidayati, N. (2014). Dinasti Politik dan Demokrasi Indonesia. Orbith: Majalah Ilmiah Pengembangan Rekayasa dan Sosial, 10(1).

6. Kartono, K. (1996). Pengantar Metode Riset Sosial. Bandung: Mandar Maju.

7. Komar, S. (2013). Dinasti Kepala Desa (Studi Tentang Survivabilitas Dinasti Politik di Desa Puput Kecamatan Simpangkatis Kabupaten Bangka Tengah) (Doctoral dissertation, Universitas Gadjah Mada).

8. Miles, M. B., \& Huberman, A. M. (1994). Qualitative Data Analysis: An Expanded Sourcebook. Thousand Oaks, CA: Sage Publications.

9. Moleong, L. J. (2014). Metode Penelitian Kualitatif. Bandung: Remaja Rosdakarya.

10. Nurcholis, H. (2011). Pertumbuhan dan Penyelenggaraan Pemerintahan Desa. Jakarta: Erlangga.

11. Pahruddin, P. (2017). Dinasti Politik Pemerintah Desa di Kabupaten Polewali Mandar. Jurnal Arajang, 1(1), 36-44. 
12. Rozali. (2015). Fenomena Dinasti Politik Pemerintahan Desa. Jurnal Ilmu Pemerintahan Fakultas Ilmu Sosial dan Ilmu Politik Universitas Maritim Raja Ali Haji.

13. Sayudi. (2014). Bentuk dan Karakter Politik Dinasti di Indonesia. Yogyakarta: Jurnal Hukum.

14. Sri, P. (2018). Politik Dinasti Dalam Kepemimpinan Desa (Studi di Desa Wawasan Kecamatan Cileunyi, Kabupaten Bandung) (Doctoral dissertation, UIN Raden Intan Lampung).

15. Tristana, R. W., \& Priyatno, H. (2017). Dinasti Politik Dalam Pemerintahan Desa di Desa Kancilan Kecamatan Kembang Kabupaten Jepara Periode 1989-2017 (Analisis Implikasi Sosial dan Politik). Journal of Politic and Government Studies, 6(03), 121-130. 